\title{
AMPLITUDES SPECTRUM COMPARISON AS A METHOD OF SELECTING WELDED JOINTS
}

DOI 10.2478/ntpe-2018-0089

\author{
mgr inż. Adam Szeleziński \\ dr inż. Adam Muc \\ dr hab. inż. Lech Murawski
}

Gdynia Martime University, Poland

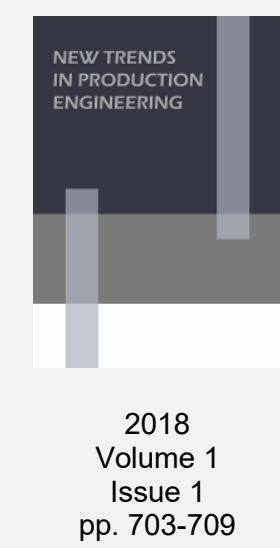

\begin{abstract}
The paper presents a comparative analysis of non-destructive testing methods used in the assessment of welded joints. The authors describe the methodology of conducting tests on welded plates using the vibration method. On the basis of the FFT analysis of responses from accelerometers, spectral characteristics were calculated, and then used along with statistical measures to develop a comparative method in non-destructive testing of welded joints. This method will make it possible to quickly and easily distinguish plates with non-defective welded joints from plates with faulty welds. The paper presents test results for a non-defective plate weld (sample no. 2202), a plate with defective edge fusion (sample no. 2127 ) and one with a cracking along the entire sample length (sample no. 2132). The article points out the limitations of the proposed method and the need for further research.
\end{abstract}

Keywords: diagnostics, welded joints, non-destructive testing, welding defects, edge fusion, vibration, statistical analysis

\section{INTRODUCTION}

The exploitation of ships creates an increased risk of disastrous damage (e.g. cracking of welded joints), which is closely connected with the safety of navigation. Out of the various modes of transport, maritime transportation (along with aviation) is exposed to relatively the highest risk. Seafaring vessels frequently operate under extremely difficult environmental conditions. In addition, marine structures (vessels, ships and offshore facilities) are exposed to a continuous influence of this aggressive environment for prolonged time periods. Each marine facility is supervised and controlled by the regulations of one of the classification societies. These require detailed periodic safety inspections of a given facility, starting from its design and construction stages. Welded joints are one of the key components subjected to detailed testing. All significant welds are tested using measurement techniques that go under the common name of NDT (Non-Destructive Testing). Non-destructive testing allows us to obtain information about the condition, properties and possible defects of the studied facility, without interfering with its usability. The technical subjects of non-destructive testing include, among others, welded joints, but also joints that are glued, bonded or soldered as well as objects made of composite materials (Biernacki et al., 1991; Lewicka-Romicka, 2001). Non-destructive testing allows one to assess the condition of welded joints without physical interference in their structure. Of course this is not the only possible method of such assessment, but it is widely used today and is being consistently developed. It is used to evaluate the quality of structural components at various stages of their life cycle, particularly at the stage of production, deployment and utilization. NDT (Non-destructive Testing) is used to achieve a high quality level of produced components and their safe usage. Non-destructive testing allows one to determine the type, size and location of defects and to assess whether a defect is admissible or that it should be removed from a given component. An important feature of NDT is the possibility to determine the properties of the material being tested and obtain its physical description (Dudzik, 2013).

Quality checks of welded joints are performed during the production process as well as for diagnostic purposes, on a facility in operation. Neglecting to conduct operating non-destructive 
tests of technical facilities (e.g. aircraft, ships, cranes, bridges etc.), or failure to comply with accepted testing standards may lead to disasters and breakdowns.

NDT testing is used in order to attain a suitably high level of quality and safety. It is used in industry and in laboratories of research centres at the stage of designing and determining the properties of new materials. Many factors influence the rapid development and routine use of NDT in the industry. The most important of those are safety and economic reasons. Safety issues were the decisive factor in introducing routine non-destructive tests in aviation, astronautics, the mining industry, nuclear power engineering and the shipping industry. The economical aspect fully justifies the necessity to use NDT in mass and volume production. Checks to ensure the quality of welds and welded joints take place in the processes prior and during production. Diagnostic operating non-destructive testing is carried out to avoid unexpected damage to technical facilities (to exclude damaged facilities from operation if the damage poses any danger for their utilisation). Failure to perform non-destructive diagnostic tests on technical facilities in operation (e.g. aircraft, ships, crane equipment) or failure to comply with accepted standards may lead to disasters and breakdowns. The predominant tendency observed in the extensive process of NDT development and improvement is to obtain as much information as possible about the state of the tested joint. This entails the possibility to detect deformations, cracks, malformations or other faults more accurately, as well as to obtain more information about them. This development leads to the acceleration of testing processes, and results in improving occupational safety and limiting the detrimental effect of substances used for testing on the health of test operators.

At present, a wide range of NDT methods are available, to which new ones are gradually being added as the technology is developed. A widely used way of testing is hybrid testing, which involves the use of mixed methods which combine two or more NDT methods. This solution makes it possible to extend the range of applications and increase the accuracy of results. Hybrid methods are divided into two groups. The first group includes tests that use the same physical phenomenon, and the second group includes tests which complement one another in terms of particular testing methods (Lewicka-Romicka, 2001). An example of a hybrid method that would be classified as group one (using the same physical phenomenon) is a combination of acoustic emissions and ultrasonic testing. During the analysis of analogous physical phenomena (e.g. mechanical wave generation) with using special measurement's equipment (e.g. piezoelectric sensors and vibration generators,), there is a possibility to carry out ongoing operational diagnostics of the tested element, which includes detecting both newly emerging defects (via acoustic emission) and the risk of the growth of already diagnosed defects (by ultrasound) (Malecki and Ranachowski, 1994). An example of a hybrid method of the second type, based on the mutual complementation between individual test methods, are thermographic tests. Thermographic tests can be used as combinations of hybrid methods based on physical phenomena such as ultrasonic vibration, eddy current, or radiation (heat, light, microwave) (Czurchryj et al., 2005). A commonly used complementary hybrid tests are surface tests combined with radiography and / or ultrasonic testing.

Industrial non-destructive test operators use the six basic NDT methods: visual testing (VT), liquid penetrant testing (PT), magnetic particle testing (MT), radiographic testing (RT), ultrasonic testing (UT) and eddy-current testing (ECT) (Mizerski, 2005). Each of the aforementioned methods has some shortcomings that have been described in an article (Szeleziński et al., 2015). Modern NDT methods, such as acoustic emission, thermography, vibrothermography, and combinations of these and conventional methods, are used for the diagnosis of special purpose facilities. The aforementioned NDT techniques are well researched and usually provide results that are reliable to a satisfactory degree. Their basic disadvantage, however, is that they are carried out only periodically. In-between testing there is no certainty as to the reliability of a given structure. This is particulary true in case of critical emergencies (i.e. extreme storm, collision, etc.), when it is essential to obtain information about the possibility to continue operating a given structure. Such information must include the level of disaster risk along with operating parameters and a specified period of safe usage. For this purpose, research is being done into new techniques named structural health monitoring 
(SHM). Structural Health Monitoring involves the use of sensors, actuators, data transmission systems and computing units integrated with the tested object for the purpose of detecting, locating, identifying and forecasting the development of defects that may cause future malfunctioning of the structure. SHM systems continuously identify structural damage. They are used in facilities where malfunctioning can pose great danger or lead to disasters. SHM diagnostics is partially based on non-destructive testing methods that are used during periodic inspections of structures in places with high probability of defects. An SHM system is a research method that utilizes elements of mechanics, electronics, IT, materials science and knowledge about the tested facility and the course of its operation. The use of SHM systems makes it possible to achieve greater usage safety and has an effect on lowering maintenance and operating costs as it allows to anticipate failures a long time before they occur, and consequently help maintenance staff to plan overhauls and repairs properly. The main difference between SHM and NDT is the hardware architecture. In SMH systems, a network of sensors is integrated with the object, while in the case of NDT we deal with an external independent network of sensors. As opposed to NDT techniques, SHM systems operate "online" (diagnose in real time). An important element of SHM systems is the automation of their operations (e.g., generating reports, informing staff about non-standard parameters) based on artificial intelligence technology.

The present paper gives an overview of using the comparative method for the evaluation of welded joints. The presented method is based on the similarity of amplitude spectra obtained during a vibration test. This method uses a modal hammer equipped with various changeable ends, including a metal and a teflon one. When testing plates using those two ends it was observed that in the case of a good weld the amplitude spectra were similar for both ends, whereas they differed considerably when plates had faulty welds. This article describes the preliminary tests used to verify this thesis, as well as their limitations.

\section{TEST BENCH AND CONDITIONS}

The laboratory test bench for testing welded joints using the vibration method and a list of the most important components are shown in Figure 1.

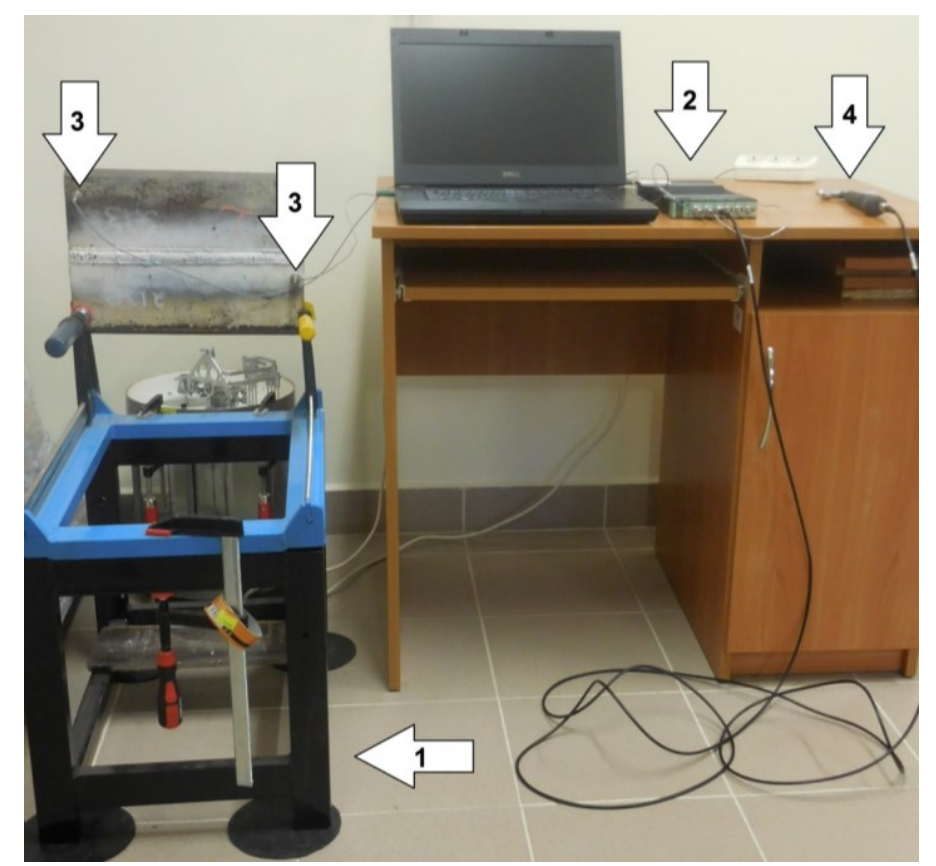

Fig. 1 Test bench for the assessment of welded joints using vibration. The test bench includes: 1- a stand where plates (welding samples) can be mounted either horizontally (four-point fixing) or vertically (two-point fixing), 2 - a Bruel \& Kjear vibration analyzer type 3050-A-60, 3 - two 4514-B accelerometers, 4 - a modular hammer (8206 - 002) with changeable ends (metal, teflon) 
At the prepared test bench, the authors carried out measurements of vibrations generated by the plates. The vibrations were caused by hitting with a modal hammer with silicone, teflon and metal ends. The test bench consisted of a stand for mounting plates (welded samples) horizontally (four-point fixing) or vertically (two-point fixing), a Bruel \& Kjear vibration analyzer type 3050-A-60, two 4514-B accelerometers, a modular hammer (8206 - 002) with three changeable ends (metal, silicone, teflon).

As part of the preliminary studies, the authors recorded the responses from accelerometers placed on the welded test plates. Next, for the recorded responses, they calculated the amplitudes using the FFT (Fast Fourier Transform) method. It follows from literature on the subject that when using the vibration method the most information about the tested object can be obtained by analysing amplitude spectra. Based on the calculated spectra, the authors verified the usefullness of different type of modal hammer ends (Szeleziński et al., 2016). Performing these actions is crucial when planning a vibration test for welded plates.

During the preliminary tests, the panels were mounted in a vertical position as shown in Figure 1. The tests were carried out on four plates. One of them, numbered " 0 " was a plate without a welded joint. The next three were welded plates and were denoted by the following numbers: 2202 - plate with a welded joint without welding defects, 2127 - plate with a faulty edge adhesion in the weld, 2132 - plate with an artificially simulated crack along the entire length. Prior to the vibration tests the welded plates were examined using radiography. That allowed for a preliminary assessment of the quality of welded joints and made it possible to identify and locate weld defects. The results of this test are shown in Figure 2.

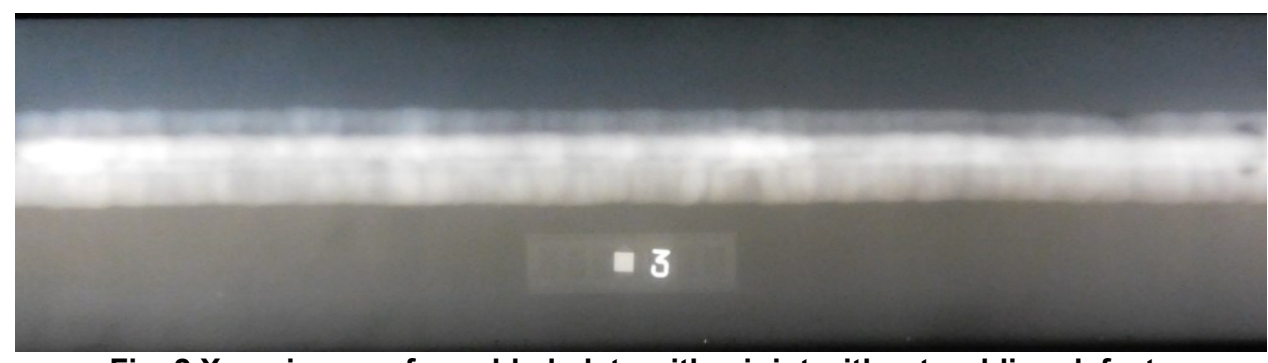

Fig. 2 X-ray image of a welded plate with a joint without welding defects

\section{THE CONCEPTION OF A COMPARATIVE METHOD}

The proposed concept of a comparative method for the evaluation of welded plates is based on preliminary results obtained by the comparison of amplitude spectras calculated for vibration responses to excitation with different modal hammer ends. Figures 3 to 5 show the amplitude spectras for vibrations of tested plates: one with non-defective welds, one with defective edge fusion and one with a cracking along the entire length. The spectral characteristics used were normalized in relation to the highest value obtained for each of the analyzed cases.

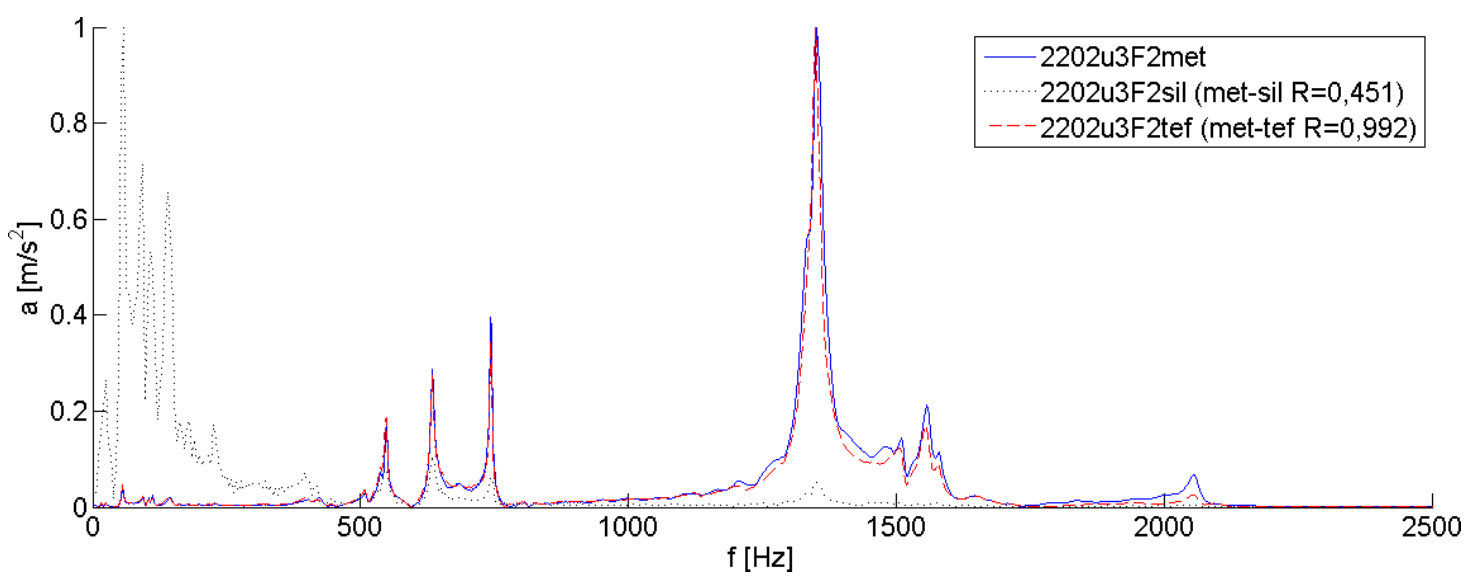

Fig. 3 Amplitude vibration spectra for a plate with a non-defective weld, type 2202 (ends: metal, silicone and teflon) 


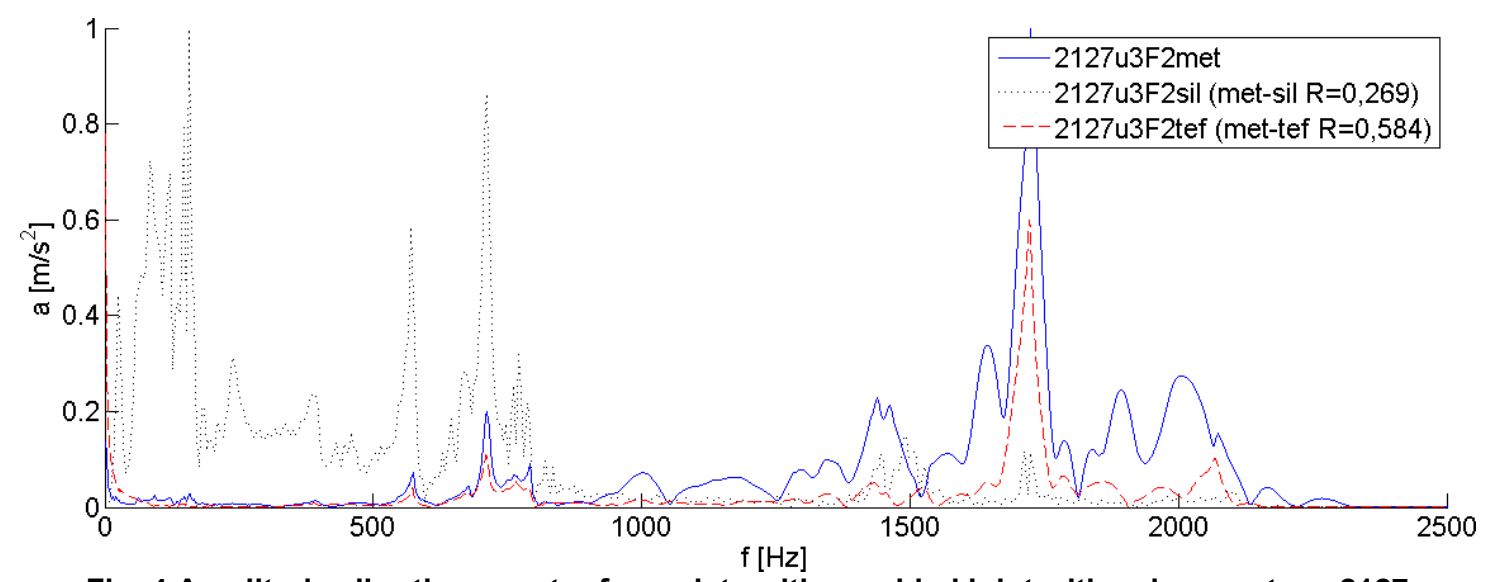

Fig. 4 Amplitude vibration spectra for a plate with a welded joint with a damage type 2127 (metal, silicone and teflon ends)

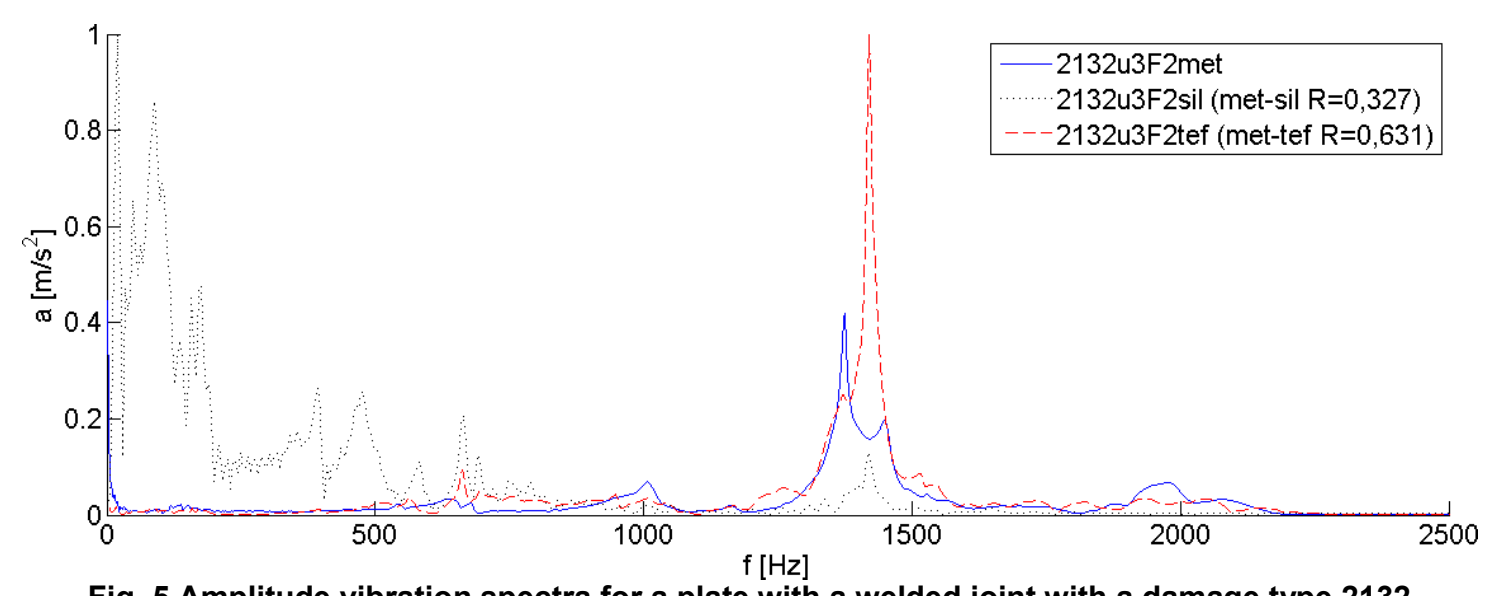

Fig. 5 Amplitude vibration spectra for a plate with a welded joint with a damage type 2132 (metal, silicone and teflon ends)

The spectral characteristics shown in Figures 3 to 5 were calculated for a non-defective welded plate and for a plate with faulty egde fusion and one with a cracking along its length, and for various modal hammer ends. A comparison of the characteristics shown in Figures 3 to 5 points to one regularity, i.e. that the results obtained for the silicone end are distinctly different from the results obtained for teflon and metal ends. The amplitude spectra for the silicone end differ greatly in shape from the rest. They are characterized by excessive excitation, especially at lower frequencies. This correlation was noted and described previously (Szeleziński et al., 2016). For this reason, the results obtained for the silicone end were not used in further analyses. It can also be seen from the presented characteristics that, for a non-defective welded plate, the spectra obtained with teflon and metal ends are very similar, whereas for the defective plates they differ considerably. Apart from the assessment based on a visual comparison of characteristics, calculations were performed to determine the $\mathrm{R}$-squared coefficient, also called the coefficient of determination. This coefficient can be used to compare and assess the degree to which two characteristics match. In the conducted tests, the spectra obtained for the metal end of the modal hammer were considered as endogenous data, while the other characteristics were seen as exogenous data. The R-squared coefficient assumes values in the interval of $(1 ; 0)$, which means that a coefficient value close to 1 indicates very good compatibility of endogenous and exogenous data. If the case is the opposite, i.e. the coefficient approaches 0 , a poor level of compatibility between the data is indicated. In the analysed cases, it was found that the best match was between results obtained for the metal and teflon ends on the non-defective welded plate, in the other cases the value of the determination coefficient was much lower, although it did not exceed 0.5. As a confirmation of the above statement,the authors observed low determination coefficient values for silicone and metal ends (not exceeding 0.5 ). 
Statistical measures were used for further investigation of similarities and differences between spectra and hammer ends. Tables 1 to 3 show the calculation of the most important statistical measures for the analysed characteristics.

Table 1

Statistical measures for plate 2202 (non-defective weld)

\begin{tabular}{|c|c|c|c|c|c|c|c|c|c|c|}
\hline \multirow{2}{*}{$\begin{array}{c}\text { Statistical } \\
\text { measure }\end{array}$} & \multicolumn{5}{|c|}{ teflon end } & \multicolumn{5}{|c|}{ metal end } \\
\hline & 1 & 2 & 3 & 4 & 5 & 1 & 2 & 3 & 4 & 5 \\
\hline Mean & $\begin{array}{l}0 \\
\stackrel{0}{0} \\
\stackrel{\omega}{0}\end{array}$ & $\begin{array}{l}\circ \\
\text { Oे } \\
\text { O্ } \\
\text { O }\end{array}$ & 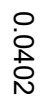 & 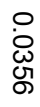 & 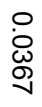 & $\begin{array}{l}\circ \\
\text { 우 } \\
\text { ㅎㅇㅇ }\end{array}$ & 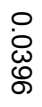 & $\begin{array}{l}\text { O } \\
\text { 离 } \\
\text { N }\end{array}$ & 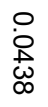 & $\begin{array}{l}\circ \\
\stackrel{\circ}{\perp} \\
\stackrel{\vec{D}}{\Delta}\end{array}$ \\
\hline Median & $\begin{array}{l}\circ \\
\stackrel{\circ}{\circ} \\
\stackrel{0}{\circ}\end{array}$ & $\begin{array}{l}\circ \\
\stackrel{\circ}{\circ} \\
\stackrel{0}{0}\end{array}$ & 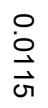 & $\begin{array}{l}\circ \\
\stackrel{\circ}{\circ} \\
\text { O }\end{array}$ & $\begin{array}{l}\circ \\
\stackrel{\circ}{\circ} \\
\stackrel{9}{0}\end{array}$ & $\begin{array}{l}\circ \\
\stackrel{\circ}{0} \\
\stackrel{0}{0}\end{array}$ & $\begin{array}{l}\stackrel{\circ}{\circ} \\
\stackrel{\circ}{\infty}\end{array}$ & $\begin{array}{l}\stackrel{\circ}{\circ} \\
\stackrel{\vec{\omega}}{\omega}\end{array}$ & $\begin{array}{l}\circ \\
\stackrel{0}{\stackrel{N}{N}}\end{array}$ & $\begin{array}{l}\stackrel{\circ}{\circ} \\
\text { के }\end{array}$ \\
\hline Standard deviation & $\begin{array}{l}\circ \\
\stackrel{0}{0} \\
\stackrel{0}{0}\end{array}$ & $\begin{array}{l}\circ \\
\stackrel{\circ}{\circ} \\
\stackrel{0}{D}\end{array}$ & 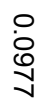 & $\begin{array}{l}\circ \\
\dot{O} \\
\text { D } \\
\mathbb{\infty} \\
N\end{array}$ & $\begin{array}{l}0 \\
\dot{0} \\
0\end{array}$ & $\begin{array}{l}0 \\
\dot{0} \\
\text { of }\end{array}$ & $\begin{array}{l}0 \\
\dot{0} \\
\stackrel{0}{\infty}\end{array}$ & $\begin{array}{l}\stackrel{\circ}{0} \\
\stackrel{\leftrightarrow}{\mathcal{U}}\end{array}$ & $\begin{array}{l}\stackrel{\circ}{\vec{D}} \\
\text { N }\end{array}$ & $\begin{array}{l}\circ \\
\dot{0} \\
\text { जै }\end{array}$ \\
\hline Sample variance & $\begin{array}{l}\circ \\
\text { ᄋ̊ } \\
\text { ơ }\end{array}$ & 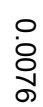 & 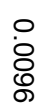 & 옹 & $\begin{array}{l}\circ \\
\stackrel{\circ}{\circ} \\
\stackrel{\infty}{\circ}\end{array}$ & $\begin{array}{l}0 \\
8 \\
8 \\
0 \\
N\end{array}$ & $\begin{array}{l}\circ \\
\text { 응 } \\
8\end{array}$ & $\begin{array}{l}\circ \\
\dot{8} \\
\text { \& } \\
\text { or }\end{array}$ & $\begin{array}{l}\circ \\
\stackrel{0}{\circ} \\
\stackrel{0}{+}\end{array}$ & $\begin{array}{l}\circ \\
\dot{8} \\
\text { 요 }\end{array}$ \\
\hline
\end{tabular}

Table 2

Statistical measures for plate 2127 (edge adhesion)

\begin{tabular}{|c|c|c|c|c|c|c|c|c|c|c|}
\hline \multirow{2}{*}{$\begin{array}{c}\text { Statistical } \\
\text { measure }\end{array}$} & \multicolumn{5}{|c|}{ teflon end } & \multicolumn{5}{|c|}{ metal end } \\
\hline & 1 & 2 & 3 & 4 & 5 & 1 & 2 & 3 & 4 & 5 \\
\hline Mean & $\begin{array}{l}\stackrel{\circ}{\vec{N}} \\
\stackrel{\text { U }}{N}\end{array}$ & $\begin{array}{l}\circ \\
\text { \&্} \\
\text { \&్ల }\end{array}$ & $\begin{array}{l}\circ \\
\stackrel{\circ}{\circ} \\
\stackrel{\circ}{V}\end{array}$ & $\begin{array}{l}\stackrel{\circ}{\vec{N}} \\
\stackrel{+}{\Delta}\end{array}$ & $\stackrel{\circ}{\stackrel{\vec{v}}{\beth}}$ & $\begin{array}{l}\circ \\
\text { 으 } \\
\text { هి }\end{array}$ & $\begin{array}{l}0 \\
\stackrel{0}{0} \\
0\end{array}$ & $\begin{array}{l}\circ \\
\text { N } \\
\text { OI }\end{array}$ & $\begin{array}{l}\stackrel{\circ}{ } \\
\stackrel{\mathcal{N}}{\omega} \\
\underset{\Theta}{ }\end{array}$ & 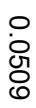 \\
\hline Median & $\begin{array}{l}\circ \\
\text { ○े } \\
\text { ले }\end{array}$ & $\begin{array}{l}0 \\
\text { 怘 } \\
\text { 吕 }\end{array}$ & $\begin{array}{l}\circ \\
\stackrel{0}{\mathscr{\omega}} \\
\stackrel{\Delta}{ \pm}\end{array}$ & $\begin{array}{l}0 \\
\text { Oे } \\
\text { ్ㅐ }\end{array}$ & $\begin{array}{l}\circ \\
\dot{0} \\
\stackrel{8}{0}\end{array}$ & 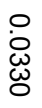 & 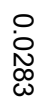 & $\begin{array}{l}\circ \\
\stackrel{0}{\circ} \\
\text { मे }\end{array}$ & $\begin{array}{l}\stackrel{\circ}{\stackrel{\circ}{\vec{\omega}}} \\
\stackrel{0}{2}\end{array}$ & $\begin{array}{l}\circ \\
\text { ㅇ. } \\
\text { N } \\
\text { on }\end{array}$ \\
\hline Standard deviation & 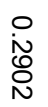 & $\begin{array}{l}\stackrel{\circ}{\vec{\omega}} \\
\stackrel{\vec{\infty}}{\infty}\end{array}$ & $\begin{array}{l}\stackrel{0}{\stackrel{N}{N}} \\
\vec{\oplus}\end{array}$ & $\begin{array}{l}\stackrel{0}{N} \\
\stackrel{\omega}{N}\end{array}$ & $\begin{array}{l}\stackrel{0}{N} \\
\stackrel{N}{N}\end{array}$ & $\begin{array}{l}\stackrel{\circ}{\vec{N}} \\
\text { UN }\end{array}$ & $\begin{array}{l}\stackrel{\circ}{\vec{\omega}} \\
\stackrel{\overrightarrow{0}}{0}\end{array}$ & ○ & $\begin{array}{l}\circ \\
\stackrel{\circ}{\omega} \\
\text { U్ర }\end{array}$ & $\begin{array}{l}\circ \\
\text { Oे } \\
\text { N } \\
\text { N }\end{array}$ \\
\hline Sample variance & $\begin{array}{l}\circ \\
\stackrel{0}{0} \\
\dot{1} \\
\text { N }\end{array}$ & $\begin{array}{l}\stackrel{0}{0} \\
\stackrel{\circ}{\stackrel{0}{0}} \\
\text { N }\end{array}$ & $\begin{array}{l}\circ \\
0 \\
0 \\
\text { co } \\
N\end{array}$ & 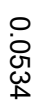 & $\begin{array}{l}\text { Oे } \\
\text { Oे } \\
\text { Eे }\end{array}$ & $\begin{array}{l}\circ \\
\stackrel{\circ}{\circ} \\
\text { 용 }\end{array}$ & $\begin{array}{l}\circ \\
\stackrel{\circ}{N} \\
\text { N }\end{array}$ & 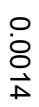 & $\begin{array}{l}\stackrel{\circ}{\circ} \\
\stackrel{\circ}{\vec{A}}\end{array}$ & $\begin{array}{l}\circ \\
\stackrel{8}{8} \\
\infty \\
\infty\end{array}$ \\
\hline
\end{tabular}

Table 3

Statistical measures for plate 2132 (cracking along the sample length)

\begin{tabular}{|c|c|c|c|c|c|c|c|c|c|c|}
\hline \multirow{2}{*}{$\begin{array}{c}\text { Statistical } \\
\text { measure }\end{array}$} & \multicolumn{5}{|c|}{ teflon end } & \multicolumn{5}{|c|}{ metal end } \\
\hline & 1 & 2 & 3 & 4 & 5 & 1 & 2 & 3 & 4 & 5 \\
\hline Mean & $\begin{array}{l}\circ \\
\text { O } \\
\text { ᄋ }\end{array}$ & $\begin{array}{l}\text { 엉 } \\
\text { 옷 }\end{array}$ & $\begin{array}{l}\text { 영 } \\
\text { 응 }\end{array}$ & $\begin{array}{l}0 \\
\text { Oे } \\
\text { Oे }\end{array}$ & $\begin{array}{l}0 \\
\stackrel{0}{0} \\
0 \\
0\end{array}$ & $\begin{array}{l}\circ \\
\stackrel{\circ}{\circ} \\
\overrightarrow{\vec{v}}\end{array}$ & $\begin{array}{l}0 \\
\text { OO } \\
\text { O } \\
\text { or }\end{array}$ & $\begin{array}{l}\circ \\
\stackrel{\circ}{\mathcal{N}} \\
\text { On }\end{array}$ & $\begin{array}{l}0 \\
\dot{8} \\
\stackrel{0}{\omega}\end{array}$ & $\begin{array}{l}\stackrel{\circ}{\circ} \\
\stackrel{\circ}{\omega}\end{array}$ \\
\hline Median & $\begin{array}{l}0 \\
\text { Oे } \\
\text { N } \\
\text { N }\end{array}$ & $\begin{array}{l}\circ \\
\stackrel{\circ}{0} \\
\text { N్ల్ర }\end{array}$ & $\begin{array}{l}0 \\
\stackrel{\circ}{\mathcal{O}} \\
\stackrel{\omega}{U}\end{array}$ & $\begin{array}{l}0 \\
\dot{8} \\
\dot{0} \\
0\end{array}$ & $\begin{array}{l}\text { O } \\
\stackrel{\circ}{\mathscr{W}} \\
\stackrel{\leftrightarrow}{\perp}\end{array}$ & 영 & $\begin{array}{l}\circ \\
\stackrel{\circ}{\circ} \\
\stackrel{\circ}{\perp}\end{array}$ & $\begin{array}{l}0 \\
\dot{8} \\
\stackrel{0}{0} \\
N\end{array}$ & $\begin{array}{l}\circ \\
\text { 옷 } \\
\text { 品 }\end{array}$ & $\begin{array}{l}\text { 옹 } \\
\text { ه্ }\end{array}$ \\
\hline Standard deviation & $\begin{array}{l}\stackrel{\circ}{\vec{\Delta}} \\
\stackrel{\vec{\Delta}}{\text { D }}\end{array}$ & $\begin{array}{l}\circ \\
\dot{0} \\
\stackrel{0}{N}\end{array}$ & $\begin{array}{l}\stackrel{\circ}{\vec{N}} \\
\stackrel{\mathscr{O}}{0}\end{array}$ & $\begin{array}{l}\circ \\
\stackrel{\circ}{\circ} \\
\stackrel{\circ}{*}\end{array}$ & $\begin{array}{l}\stackrel{\circ}{\vec{\sigma}} \\
\stackrel{\circ}{\sigma}\end{array}$ & 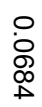 & $\begin{array}{l}\text { O } \\
\text { Oे } \\
\text { 心 } \\
\perp\end{array}$ & $\begin{array}{l}\stackrel{\circ}{0} \\
\stackrel{N}{\Xi}\end{array}$ & $\begin{array}{l}0 \\
\stackrel{0}{0} \\
\stackrel{0}{\omega}\end{array}$ & 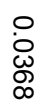 \\
\hline Sample variance & $\begin{array}{l}\circ \\
\stackrel{\circ}{0} \\
\stackrel{0}{0}\end{array}$ & $\begin{array}{l}\stackrel{\circ}{\circ} \\
\stackrel{\leftrightarrow}{\overrightarrow{0}}\end{array}$ & $\begin{array}{l}\circ \\
\stackrel{\circ}{\circ} \\
\text { ㅇ }\end{array}$ & $\begin{array}{l}\circ \\
\text { O } \\
\text { N }\end{array}$ & 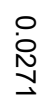 & $\begin{array}{l}\circ \\
\dot{8} \\
\stackrel{1}{*}\end{array}$ & $\begin{array}{l}\text { O } \\
\text { ठे } \\
\text { जे }\end{array}$ & $\begin{array}{l}\circ \\
\dot{8} \\
\varnothing\end{array}$ & $\begin{array}{l}\circ \\
\varnothing \\
\varnothing\end{array}$ & $\begin{array}{l}\stackrel{\circ}{\circ} \\
\stackrel{\circ}{v}\end{array}$ \\
\hline
\end{tabular}


Comparing the results shown in Tables 1 to 3 , it can be concluded that for the plate with nondefective welding the statistical measures confirm the correlation between the amplitude spectra obtained for the metal and teflon ends. On the other hand, such compatibility was not observed in cases where there was a welding defect, where metal and teflon ends were used.

\section{FINAL CONCLUSIONS}

The presented conception for a comparative assessment method for welded plates should be seen as a proposal of a measurement method. At the same time, it is necessary to point out the need for further tests, which should be repeated on a larger sample set. In particular, it would be necessary to confirm the compatibility of the results obtained for non-defective welded plates and to examine what spectral characteristics would look like for defects other than just edge fusion or cracking. Regardless of the above, the proposed comparative method offers the possibility to differentiate between plates with non-defective welds and welded plates with defects. The main advantage of this method would be its speed and simplicity, which stem from the fact that, with a relatively small amount of calculations, it is sufficient to compare selected statistical measures obtained for two tests: with metal and teflon hammer ends. If results are convergent, it can be concluded that the weld is well made, while if there is a large discrepancy - which has to be defined through experimentation - that the weld has defects. In a modified form, the method can also be implemented for on-going operational tests within Structural Health Monitoring (SHM) systems.

The method does not allow to identify the type of a weld defect. To achieve that, a more accurate method would have to be used, such as the analysis of amplitude or phase characteristics or time vibration in welded joints. The authors are planning to develop a SHM system for marine construction testing. What is especially important is the monitoring of welded joints in heavily exploited ships. Having reviewed existing methods of diagnostics and construction monitoring, the authors have selected methods based on fiber optic sensors and analyses of the dynamic characteristics of the tested parts of hull structure, ship machinery and equipment.

\section{REFERENCES}

Biernacki, B., Jawor, R., Kozak, T., Lipnicki, M., Marchwicki, M., Niezborała, J. Puchaczewski, N., Świątkowski, R. (1991). Badania metodami nieniszczącymi, Laboratorium Badań Nieniszczących. Gdańsk: KOLI

Lewicka-Romicka, A. (2001). Badania nieniszczące. Podstawy defektoskopii. Warszawa: Wydawnictwo Naukowo-Techniczne

Dudzik, S. (2013). Wyznaczenie głębokości defektów materiałowych z zastosowaniem aktywnej termografii dynamicznej i sztucznych sieci neuronowych. Częstochowa: Wydawnictwo Politechniki Częstochowskiej

Malecki, I., Ranachowski, J. (1994). Emisja akustyczna źródła, metody, zastosowania. Warszawa: Biuro Pascal

Czurchryj, J., Papkala, H., Winiowski, A. (2005). Niezgodności w złączach spajanych. Gliwice: Instytut Spawalnictwa

Mizerski, J. (2005). Spawanie wiadomości podstawowe. Warszawa: Wydawnictwo REA

Szeleziński, A., Gesella, G., Murawski, L. (2015). Przegląd metod diagnostyki i monitoringu połączeń spawanych w konstrukcjach transportu morskiego. Logistyka Volume 3

Szeleziński, A., Murawski, L., Muc, A. (2016). Analysis of ability to detect defects in welding structures with usage of dynamic characteristics spectrum. Journal of KONES, $\mathrm{Nr} 23$

Arczewski, K., Pietrucha, J., Szuster, J. (2008). Drgania układów fizycznych. Warszawa: Oficyna Wydawnicza Politechniki Warszawskiej

Awrejcewicz, J., Krysko, W. (2000). Drgania układów ciągłych. Warszawa: Wydawnictwa Naukowo-Techniczne

Szeleziński, A., Murawski, L., Muc, A., Gesella, G. (2016). Wybór końcówki młotka modalnego i miejsca uderzenia w badaniach metodą drganiową płyt spawanych. Gdynia: Zeszyty Naukowe Akademii Morskiej w Gdyni 